\title{
Physiological energetics of mussel larvae (Mytilus edulis). I. Shell growth and biomass
}

\author{
Martin Sprung*
}

Biologische Anstalt Helgoland, Meeresstation, D-2192 Helgoland, Federal Republic of Germany

\begin{abstract}
Development and shell growth of the larvae of the marine mussel Mytilus edulis L. were recorded in laboratory cultures. Experiments were conducted at 6,12 and $18^{\circ} \mathrm{C}$ and food concentrations of $1,2,5,10,20$, and 40 Isochrysis galbana cells $\mu^{-1}$. After fertilization, the eggs developed to the Dshaped stage within $104 \mathrm{~h}$ at $6^{\circ} \mathrm{C}, 42 \mathrm{~h}$ at $12^{\circ} \mathrm{C}$, and $32 \mathrm{~h}$ at $18^{\circ} \mathrm{C}$. Rearing was not successful with $1 I$. galbana cell $\mu l^{-1}$. At other food conditions, growth rate increased with concentration of $I$. galbana up to a plateau at about 10 cells $\mu l^{-1}$. Growth curves (shell length vs. time) were sigmoidal at the lowest food concentrations at $6^{\circ} \mathrm{C}$; in all other cases they were linear with a maximum rate of $3.4 \mu \mathrm{m} \mathrm{d}^{-1}$ at $6^{\circ} \mathrm{C}, 8.1 \mu \mathrm{m} \mathrm{d} \mathrm{d}^{-1}$ at $12^{\circ} \mathrm{C}$, and $11.8 \mu \mathrm{m} \mathrm{d}^{-1}$ at $18^{\circ} \mathrm{C}$. Total dry weight and ash weight were estimated for various larval stages. Based on these data, tissue dry weight, tissue wet weight, total wet weight and shell weight were calculated. Eggs, trochophores and the food organism I. galbana were analysed for their elemental composition (CHN). Body growth was estimated by data on shell growth and body weight.
\end{abstract}

\section{INTRODUCTION}

The bivalve Mytilus edulis L is a typical benthic invertebrate of many temperate marine coasts. It reproduces by means of a planktonic larva. Characteristics of this reproductive strategy are: (1) High fecundity (Thompson, 1979; Bayne et al., 1983; Sprung, 1983); (2) high larval mortality - up to more than $99 \%$ has been estimated for various bivalves (Thorson, 1946; Yap, 1977; Gledhill, 1980; Brousseau et al., 1982); (3) high dispersal - in contrast to the adult phase (Crisp, 1974, 1975).

Mytilus edulis is of separate sex. The eggs are fertilized after being released into the water. Its subsequent development has been described e.g. by Field (1922) and Bayne (1976). It can be divided into 3 distinct phases:

Lecithotrophic phase: it takes a few days and comprises cleavage, formation of cilia (trochophore stage), a velum and a shell gland. This phase ends with the secretion of a D-shaped shell of 100 to $120 \mu \mathrm{m}$ length.

Growth phase: the larva starts feeding and increases in weight. Growth rings are secreted by the mantle

\footnotetext{
- Present address: Physiological Ecology Section, Department of Zoology, University of Köln, Weyertal 119, D-5000 Köln 41, Federal Republic of Germany
}

edges, and the shell loses its D-shape. This stage is called 'veliconcha' (Werner, 1940). It persists for some weeks.

Settling phase: at about $270 \mu \mathrm{m}$ shell length a foot has developed next to the velum, with which the larva tests the substrate for settling. This pediveliger stage (Carriker, 1956, 1961) can, however, stay in the plankton up to a shell length of $360 \mu \mathrm{m}$ (own obs.). It has been excluded to a great extent from these experiments, because Bayne $(1965,1971)$ has examined it for Mytilus edulis.

Although the morphology of Mytilus larvae has been frequently described in the literature (e.g. Le Pennec and Masson, 1976; Booth, 1977; Lutz and Hidu, 1979; Le Pennec, 1980; older literature reviewed by Bayne, 1976), data on its physiology have been rare up to recent years.

This is due to practical reasons. Although the first successful rearing of Mytilus larvae dates back to Matthews (1913), many difficulties had to be overcome in developing rearing techniques, especially in testing adequate food. Experiments focussed mainly on commercially important species. Much work done during the past 4 decades has been devoted to this aspect (reviewed by Loosanoff and Davis, 1963 and Walne, 1979).

Progress in ecosystem research has prompted the 
need for data on energy budgets of important species (Jørgensen, 1983). Thus, during the past years research in this field has been enhanced. For bivalve larvae, in addition to older publications (Jørgensen, 1952; Walne, 1965; Gabbott and Holland, 1973), the papers of Riisgård et al. (1980, 1981), Jespersen and Olsen (1982) and Gerdes (1983 a, b) must be mentioned in this context.

In a series of 4 papers the attempt is made to estimate important budget data of Mytilus edulis larvae at 3 temperatures with respect to larval size and to food concentration. Here the results of experiments on development and shell growth as well as weight data are presented. Subsequent papers will deal with food uptake, respiration and ecologically relevant efficiencies.

\section{MATERIALS AND METHODS}

\section{General conditions}

Mussels with ripe gametes were brought from the rocky shore of Helgoland into the laboratory during spring. They were kept at 7 to $9{ }^{\circ} \mathrm{C}$ and fed with Dunaliella tertiolecta and Isochrysis galbana for several weeks or months until the beginning of experiments.

For stimulating them to spawn, the mussels were cleaned with tap water and transferred separately into $250 \mathrm{ml}$ Erlenmeyer flasks. The flasks were filled with water of $18^{\circ} \mathrm{C}$ and placed in a $12^{\circ} \mathrm{C}$ temperatureconstant room. The water was vigorously aerated. After spawning, the eggs were filtered through a sieve of $112 \mu \mathrm{m}$ mesh size and the sperm through a sieve of $40 \mu \mathrm{m}$ mesh size in order to remove faeces and other particles.

Larvae were reared in $5 \mathrm{l}$ bottles filled with $0.45 \mu \mathrm{m}$ membrane filtered seawater of 28 to $33 \%$ salinity The bottles were placed in temperature-constant rooms of 6. 12 and $18^{\circ} \mathrm{C}$ under artificial light with a diurnal rhythm. They were slightly aerated.

The cultures were started with a density of about 10 to 30 eggs $\mathrm{ml}^{-1}$. Eggs were inseminated by a droplet of sperm. Water was changed for the first time, when most larvae had formed a D-shell, i.e. after 2 d at $18^{\circ} \mathrm{C}$, after $3 \mathrm{~d}$ at $12^{\circ} \mathrm{C}$ and after $5 \mathrm{~d}$ at $6^{\circ} \mathrm{C}$, and later on every tenth day. Larvae were then sieved off on a screen of 40 $\mu \mathrm{m}$ mesh size (larger mussels on 112 and $150 \mu \mathrm{m}$ mesh size); dead larvae or unfertilized eggs were left on the bottom of the experimental vessel and discarded.

Larvae were fed exclusively with the flagellate Isochrysis galbana from the first water change on. The alga was cultivated at $10^{\circ} \mathrm{C}$ in $\mathrm{f} / 2$ medium (Guillard and Ryther, 1962). By means of this low and suboptimal temperature (Kain and Fogg, 1958) algae were prevented from sticking together and sinking to the bottom especially in the $6^{\circ} \mathrm{C}$ cultures. The algae were spun off before use.

\section{Development to the D-larva}

Immediately after spawning, eggs and sperm were brought into temperature-constant rooms of 6,12 and $18^{\circ} \mathrm{C}$. Gametes were adapted to the temperature for $1 \mathrm{~h}$. Eggs were inseminated by a droplet of sperm. Every $20 \mathrm{~min}$ (later, at longer intervals) a sample was classified under a microscope according to the drawings of Field (1922). The group with the most advanced stage was taken as reference.

\section{Shell growth}

Deviating from the rearing conditions described above, cultures were started with a concentration of about 1 egg $\mathrm{ml}^{-1}$. Water was changed every fifth day at 12 and $18^{\circ} \mathrm{C}$ and every tenth day at $6^{\circ} \mathrm{C}$ with a $40 \mu \mathrm{m}$ sieve irrespectively of larval size. Food concentration was standardized to $1,2,5,10,20$ and 40 Isochrysis cells $\mu \mathrm{l}^{-1}$; it was kept fairly constant by maintaining an equilibrium of feeding mussels and growing algae. Algal concentration was checked daily by means of a Coulter Counter and corrected if necessary.

At every water change the shell length of 20 and later in the experiment of 30 larvae taken at random was measured by means of a micrometer with an accuracy of $\pm 6 \mu \mathrm{m}$. The largest 10 or 15 , respectively were selected and the arithmetic mean and the standard deviation determined. By means of this procedure a bias caused by crippled animals was avoided. These data are thus compatible with estimates of weight, feeding and respiration, where crippled mussels were discarded by coarser mesh sizes at the water changes.

The cultures were terminated when either the first animals had settled on the bottom of the vessel or when no survivours were left.

\section{Weight data}

Specimens were sampled by means of a sieve (40, 112, or $150 \mu \mathrm{m}$ mesh size according to the larval size) from the surface water of the cultures. They were resuspended in a small volume (ca. 10 to $50 \mathrm{ml}$ ) of $0.45 \mu \mathrm{m}$ filtered seawater. The larval density in this volume was estimated by subsampling: eggs and trochophores were counted with a Coulter Counter; 
with the veliconcha 16 times $1 \mathrm{ml}$ was checked under a dissecting microscope after an appropriate dilution of the subsample. Defined quantities of this small volume (in most cases $1 \mathrm{ml}$ ) were filtered off on pre-ashed and pre-weighed glass fibre filters, which had been punched to a diameter of $8 \mathrm{~mm}$. Only the pediveligers were counted individually.

The larvae were washed twice with double distilled water and subsequently freeze-dried for at least $6 \mathrm{~h}$. Often they were stored at $-18^{\circ} \mathrm{C}$ until analysis. Before determining the dry weight on an electronic autobalance (Perkin-Elmer AD-2) they were freeze-dried again. For removing the organic substance, the filters were ashed for $3 \mathrm{~h}$ at $500^{\circ} \mathrm{C}$ and reweighed. The data were corrected by means of blank tests.

The larvae examined had been cultivated at $12^{\circ} \mathrm{C}$ except the pediveligers which had been cultivated at $6^{\circ} \mathrm{C}$. They had been starved for several hours to one day prior to filtration.

Following parameters were calculated from the dry and the ash weight: Ash free dry weight: difference between total dry weight and ash weight. Shell weight: from the ash weight assuming that $5.8 \%$ of the shell is ash and that the ash content of the soft body is negligible (according to data of adult mussels from Sprung, 1980; see also Jespersen and Olsen, 1982). Tissue dry weight: difference between total dry weight and shell weight. Tissue wet weight: from the tissue dry weight assuming that $81 \%$ of the soft body consists of water (according to data of adult mussels from Sprung, 1980). Total wet weight: sum of shell weight and tissue wet weight.
Elemental composition of eggs, trochophores and the food organism Isochrysis galbana was determined in a CHN-analyser (Carlo Erba, Mod. 1106). The analyser was calibrated after every tenth sample with acetanilid (2-3 calibrations). The $I$. galbana concentration was estimated by means of a Coulter Counter. As preliminary experiments showed, washing with distilled water caused a loss of organic substance of the alga. This step was thus left out in the analytical procedure. Samples were evaluated with respect to the elemental composition of the ashed filters.

\section{RESULTS}

The sequence of developmental stages is described in Fig. 1. At $18^{\circ} \mathrm{C}$ the first group of larvae developed to the $\mathrm{D}$-shaped stage within $32 \mathrm{~h}$ after fertilization, at $12^{\circ} \mathrm{C}$ within $42 \mathrm{~h}$ and at $6^{\circ} \mathrm{C}$ within $104 \mathrm{~h}$.

Fig. 2 gives growth data and fitted growth curves. In most cases a linear fit showed the highest correlation coefficient; therefore it was applied here. Only at the 3 lowest food concentrations tested at $6^{\circ} \mathrm{C}$ was a sigmoidal growth curve evident. These curves have been fitted by eye, because all curve fittings tested gave too high growth rates at the point of inflexion compared with those of the other food concentrations. At a food concentration of 1 Isochrysis cell $\mu 1^{-1}$ many larvae started growing However, none reached the pediveliger stage. All other food concentrations were high enough to rear larvae successfully.
Fig. 1. Mytilus edulis, larvae. Time sequence of some steps in the development of the fertilized egg at experimental temperatures; lines fitted by eye; 1 : first polar body; 2: second polar body; 3: first cleavage (unequal); 4 : second cleavage (equal); 5: first cleavage of the micromeres; 6: micromeres start growing around macromeres; 7 : micromeres surround macromeres completely; 8 : larva starts swimming; 9: flagellum is formed; 10: velum is formed; 11: formation of a D-shaped shell completed

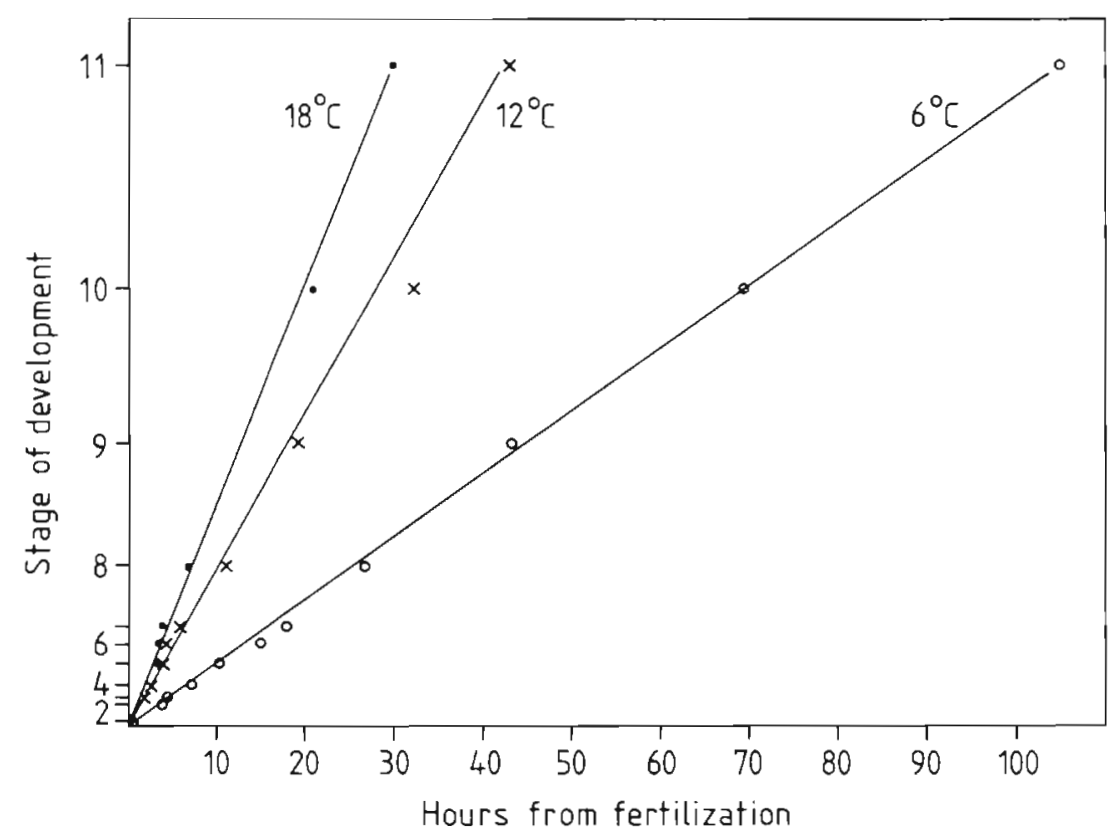



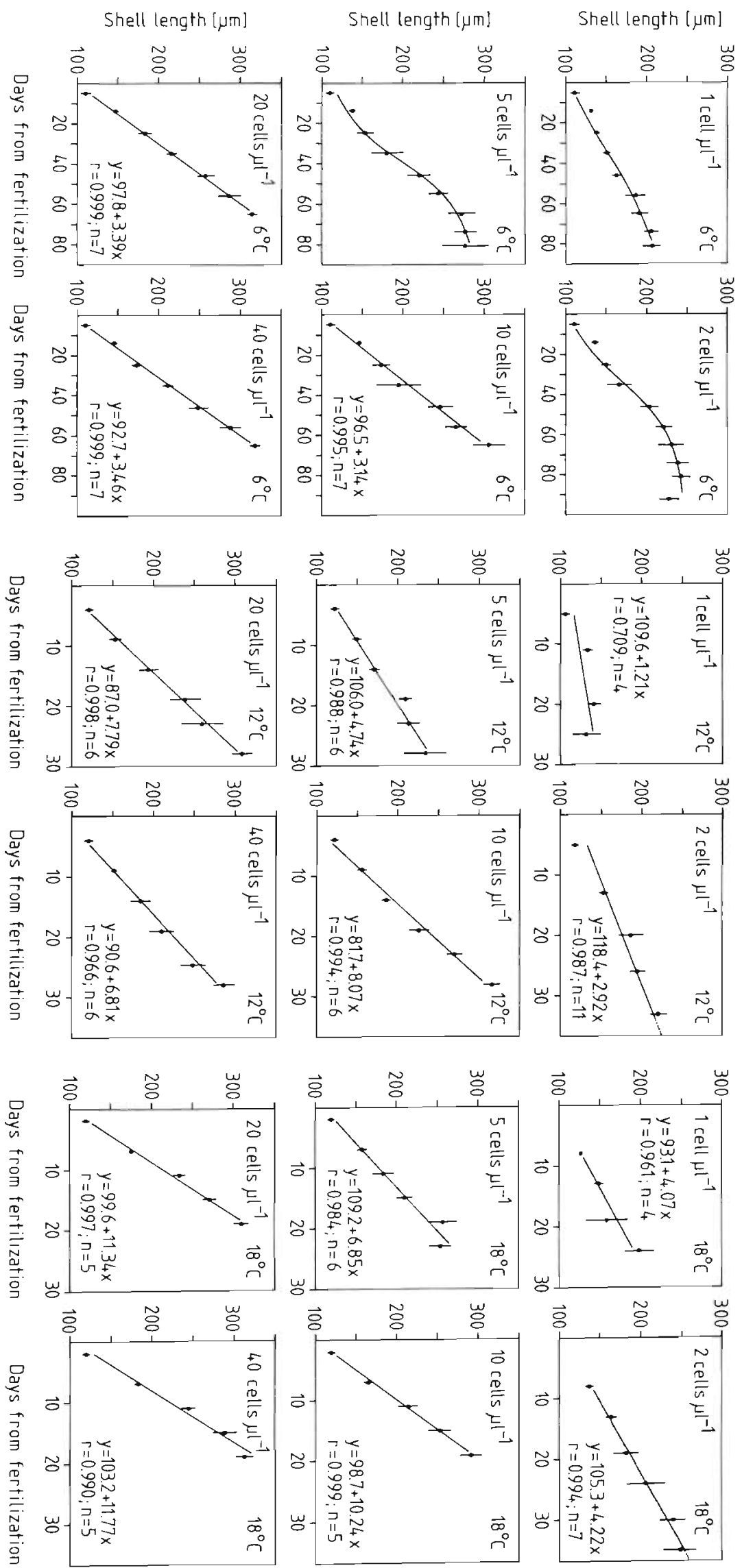

Fig. 2. Mytilus edulis, larvae. Shell growth at various food concentrations (Isochrysis cells $\mu^{-1}$ ) and experimental temperatures; for fit and manipulation of data points see text; $y$ : shell length $(\mu \mathrm{m})$; $\mathrm{x}$ : days from fertilization; $\mathrm{r}$ : correlation coefficient; $n$ : number of data points 


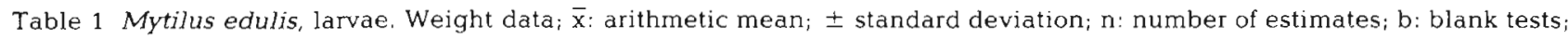
see text for further explanations

\begin{tabular}{|c|c|c|c|c|c|c|c|c|c|c|c|c|c|c|}
\hline \multirow[t]{2}{*}{ Stage } & \multicolumn{3}{|c|}{$\begin{array}{l}\text { Egg diameter or } \\
\text { shell length }(\mu \mathrm{m})\end{array}$} & \multicolumn{3}{|c|}{$\begin{array}{l}\text { Total dry weight } \\
\text { (ng) }\end{array}$} & \multicolumn{3}{|c|}{$\begin{array}{l}\text { Ash weight } \\
\text { (ng) }\end{array}$} & \multirow{2}{*}{$\begin{array}{c}\text { Ash free } \\
\text { dry } \\
\text { weight } \\
\text { (ng) }\end{array}$} & \multirow{2}{*}{$\begin{array}{c}\text { Shell } \\
\text { weight } \\
\text { (ng) }\end{array}$} & \multirow{2}{*}{$\begin{array}{c}\text { Tissue } \\
\text { dry } \\
\text { weight } \\
\text { (ng) }\end{array}$} & \multirow{2}{*}{$\begin{array}{c}\text { Tissue } \\
\text { wet } \\
\text { weight } \\
\text { (ng) }\end{array}$} & \multirow{2}{*}{$\begin{array}{c}\text { Total } \\
\text { wet } \\
\text { weigh } \\
\text { (ng) }\end{array}$} \\
\hline & $\bar{x}$ & \pm & $\mathrm{n}$ & $\bar{x}$ & \pm & $n+b$ & $\bar{x}$ & \pm & $n+b$ & & & & & \\
\hline Egg & $\varnothing 77.8$ & 1.4 & 10 & 67.4 & 6.1 & $9+6$ & 6.0 & 1.4 & $4+3$ & 61.4 & - & 61.4 & 323 & 323 \\
\hline Trochophore & - & - & - & 51.5 & 4.4 & $11+5$ & 3.0 & 2.9 & $4+2$ & 48.5 & - & 48.5 & 255 & 255 \\
\hline D-Larva & 120 & 4 & 10 & 134.2 & 17.4 & $11+5$ & 84.2 & 6.3 & $6+3$ & 50.0 & 89.3 & 44.9 & 236 & 326 \\
\hline Veliconcha & 140 & 9 & 20 & 245.9 & 10.3 & $10+6$ & 170.3 & 7.6 & $5+3$ & 75.6 & 180.8 & 65.1 & 343 & 523 \\
\hline Veliconcha & 140 & 9 & 20 & 231.2 & 19.9 & $10+6$ & 188.8 & 25.3 & $4+3$ & 42.4 & 200.4 & 30.8 & 162 & 363 \\
\hline Veliconcha & 173 & 7 & 20 & 541.6 & 25.3 & $10+6$ & 388.1 & 13.1 & $5+3$ & 153.5 & 412.0 & 129.6 & 682 & 1094 \\
\hline Veliconcha & 173 & 7 & 20 & 491.5 & 27.5 & $10+6$ & 332.3 & 26.6 & $5+3$ & 159.2 & 352.8 & 138.7 & 730 & 1083 \\
\hline Veliconcha & 252 & 13 & 20 & 952 & 82 & $10+6$ & 626 & 91 & $5+3$ & 326 & 664.5 & 287.8 & 1515 & 2179 \\
\hline Veliconcha & 252 & 13 & 20 & 982 & 44 & $8+6$ & 671 & 22 & $4+3$ & 311 & 712.3 & 270.2 & 1422 & 2134 \\
\hline Pediveliger & 298 & 23 & 20 & 1829 & 447 & $8+8$ & 947 & 217 & $4+4$ & 882 & 1005.3 & 824.0 & 4337 & 5342 \\
\hline
\end{tabular}

Weight data have been compiled in Table 1, and the graphs describing weight as a function of shell length are given in Fig. 3. Elemental analysis of the eggs, trochophores and Isochrysis provided the results presented in Table 2.

The energy content of the larvae was calculated from its ash free dry weight, that of Isochrysis from its carbon content despite of its unusual $\mathrm{C} / \mathrm{N}$ ratio. It was assumed that $1 \mathrm{ng}$ carbon corresponded to $0.04 \mathrm{~mJ}$ Joule or $0.5 \mathrm{ng}$ ash free dry weight, respectively (Finlay and Uhlig, 1981). One Isochrysis cell must thus contain $0.608 \mu$ Joule.

The histograms in Fig. 4 have been constructed from regression lines in Fig. 3 and the data in Table 2. Relative shell weight declines with larval size. Note also that ash forms only a small part of the tissue dry substance of trochophores.

From shell growth, tissue growth was estimated (Table 3). It has been expressed in terms of absolute and relative increase in ash free dry weight. The results are illustrated in Fig. 5 and 6 . At 6 and $18^{\circ} \mathrm{C}$ growth rate increased with algal concentration. A plateau was attained at 10 cells $\mu l^{-1}$. At $12^{\circ} \mathrm{C}$ growth rates even declined at food concentrations above 10 cells $\mu \mathrm{l}^{-1}$

Relative growth rates declined constantly with larval size at the 3 temperatures and all food concentrations tested.

\section{DISCUSSION}

The lecithotrophic phase of Mytilus edulis larvae was examined by Field (1922), Rattenbury and Berg (1954) and Bayne (1965). Data of its total duration are compiled in Fig. 7
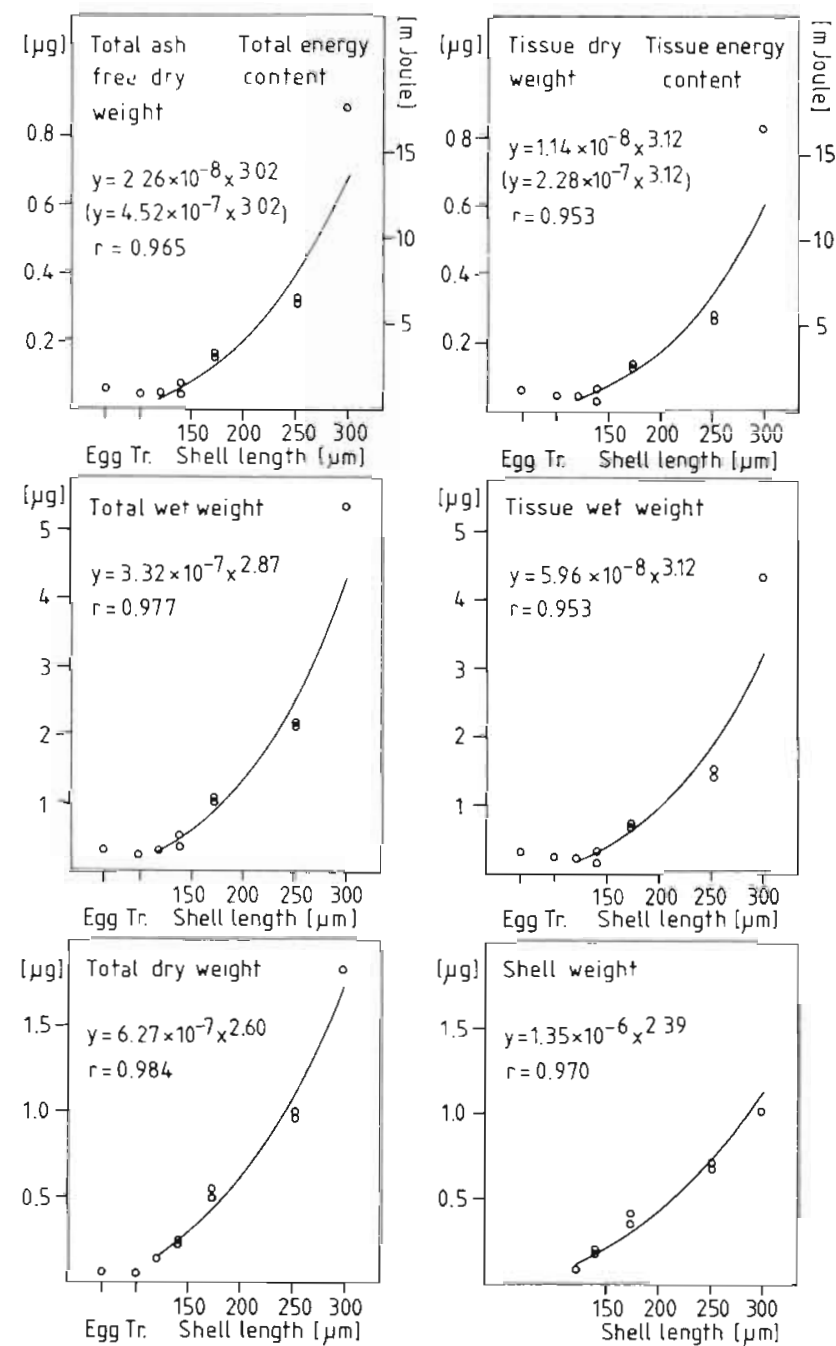

Fig. 3. Mytilus edulis, larvae. Fitted graphs and weight data (from Table 1); y: weight $(\mu \mathrm{g}) ; \mathrm{x}$ : shell length $(\mu \mathrm{m})$; $\mathrm{r}$ : correlation coefficient; equation in brackets for energy content (mJoule) 
Table 2. Elemental composition (carbon, hydrogen, nitrogen) of eggs and trochophore larvae $\left(1 \mathrm{~d}\right.$ old at $\left.12^{\circ} \mathrm{C}\right)$ of $\mathrm{Mytilus} \mathrm{edulis}$ and of its food organism Isochrysis galbana; $\bar{x}$ arithmetic mean; \pm standard deviation; $\mathrm{n}+\mathrm{b}$ number of samples and blank tests

\begin{tabular}{|c|c|c|c|c|c|c|c|c|c|c|}
\hline \multirow[t]{2}{*}{ Sample } & \multicolumn{2}{|c|}{$\mathrm{C}$} & \multicolumn{2}{|c|}{$H$} & \multicolumn{2}{|c|}{$N$} & \multirow[t]{2}{*}{ Unit } & \multicolumn{2}{|c|}{$\mathrm{C} / \mathrm{N}$} & \multirow[b]{2}{*}{$n+b$} \\
\hline & $\overline{\mathrm{x}}$ & \pm & $\overline{\mathrm{x}}$ & \pm & $\overline{\mathrm{x}}$ & \pm & & $\bar{x}$ & \pm & \\
\hline $\mathrm{Egg}(\varnothing 78 \mu \mathrm{m})$ & 32.8 & 0.8 & 5.7 & 0.2 & 6.2 & 0.2 & $\mathrm{ng}$ & 5.3 & 0.1 & $5+3$ \\
\hline Trochophore & 26.5 & 1.0 & 5.4 & 0.2 & 4.3 & 0.2 & ng & 6.1 & 0.3 & $6+3$ \\
\hline Isochrysis galbana & 15.2 & 1.1 & 2.7 & 1.1 & 0.7 & 0.1 & $\mathrm{pg}$ & 21.2 & 3.0 & $5+3$ \\
\hline
\end{tabular}

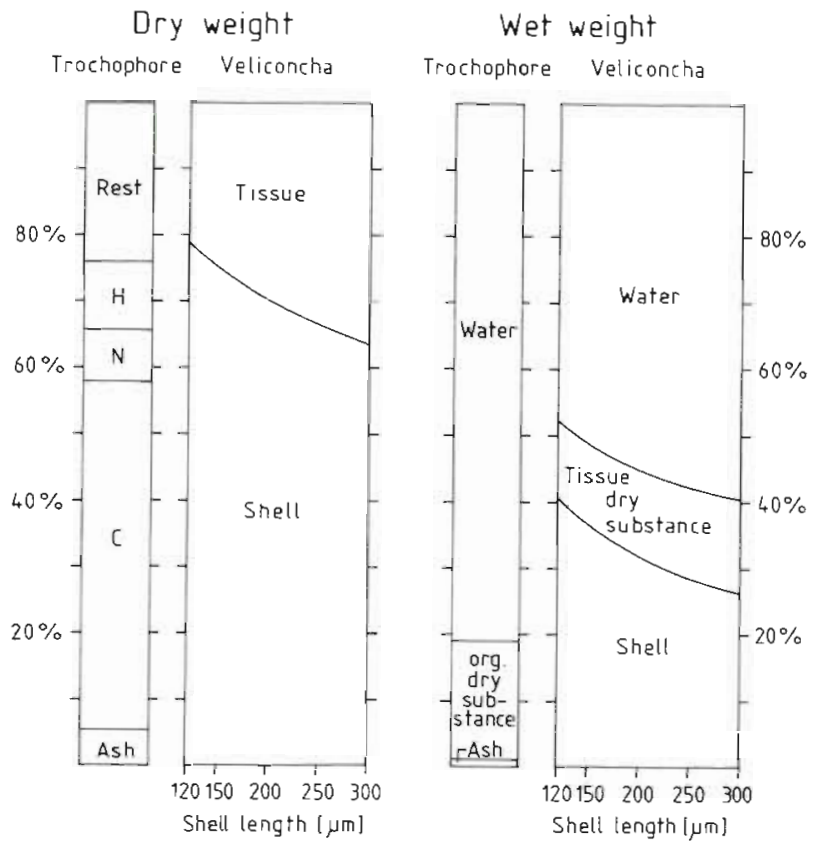

Fig. 4. Mytilus edulis, larvae. Composition of dry and wet substance (data from Table 1,2 and Fig. 3)

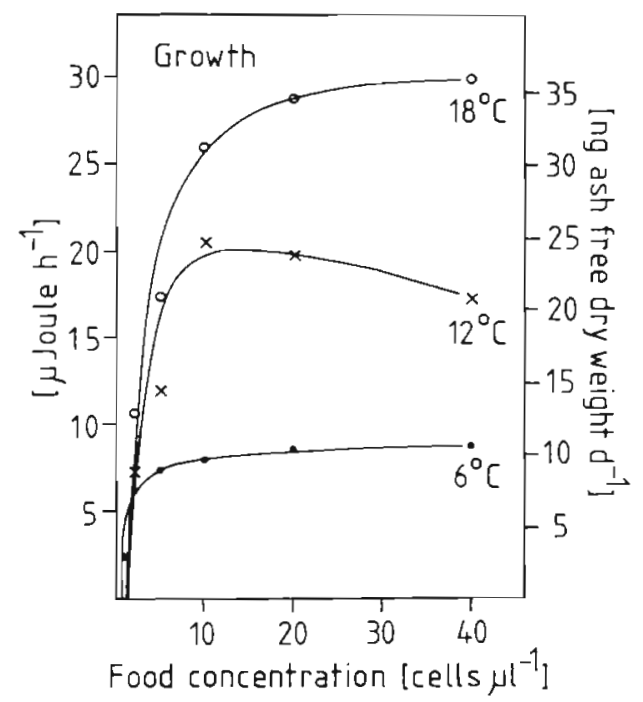

Fig. 5. Mytilus edulis, larvae (200 $\mu$ m shell length). Growth at various temperatures and food concentrations (Isochrysis cells $\left.\mu l^{-1}\right)$; graphs fitted by eye according to data from Table 3 and Sprung (1984)
Development at 12 and $18^{\circ} \mathrm{C}$ recorded here is faster than that reported elsewhere. Next to natural variation. and differences caused by pretreatment of the adults, at least 2 reasons account for this. My own experiments refer to the fastest group of larvae, whereas the other authors may have chosen the mean of all stages observed.

Secondly, according to my own experience, development is depressed in dense larval cultures. Obviously, Field's (1922) data are greatly influenced by it. This is supported by his drawings which show forms with incomplete or crippled D-shells as often encountered in overcrowded cultures.

Growth is the most frequently controlled physiological parameter in experiments with bivalve larvae. For practical reasons shell length is normally taken as reference. Here tissue growth has been calculated from shell growth. This step cannot be made without objections, because it can wipe out differences existing between the weight of larvae of the same shell length. Attention has been drawn to this fact by Lucas and Costlow (1979) working with larvae of the snail Crepidula fornicata and by Gustafson (1980) experimenting with Mya arenaria larvae.

However, Fig. 8 demonstrates that actively swimming larvae - as referred to here - show a rather distinct relation between mean body weight and shell length. The weight of larvae from the same culture after $10 \mathrm{~d}$ of starvation has been compared with the graph from Fig. 3. At $122 \mu \mathrm{m}$ shell length, 10 estimations of the dry weight and 5 estimations of the ash weight have been made; at $146 \mu \mathrm{m}$ shell length, 9 and 3 estimations; at $178 \mu \mathrm{m}$ shell length, 8 and 4 . The weight of starved and non-starved larvae was almost identical. For certain, the larvae must have lost weight during the $10 \mathrm{~d}$ due to respiratory processes. Apparently, when estimating these data, only the strongestprobably the heaviest - larvae could still swim up. Their weight just corresponded to the mean $10 \mathrm{~d}$ before with the lighter larvae included. That is why extrapolation from shell length to shell weight must be valid for actively swimming larvae.

Dry weight of bivalve larvae has been estimated by Walne (1965), Holland and Spencer (1973), Gerdes 
Table 3. Mytilus edulis, larvae. Growth data; increase in shell length $\left(\mu \mathrm{m} \mathrm{d}^{-1}\right)$; increase in ash free dry weight, absolute (ng $\mathrm{d}^{-1}$ ) and relative ( $\%$ afdw $\left.d^{-1}\right)$; calculated from data given in Fig 2 and 3

\begin{tabular}{|c|c|c|c|c|c|c|c|c|c|c|c|c|c|}
\hline \multirow{2}{*}{$\begin{array}{l}\text { Tem- } \\
\text { pera- } \\
\text { ture }\end{array}$} & \multirow{2}{*}{$\begin{array}{c}\text { Food } \\
\text { concentration } \\
\text { (Isochrysis } \\
\left.\text { cells } \mu \mathrm{I}^{-1}\right)\end{array}$} & \multicolumn{3}{|c|}{$120 \mu \mathrm{m}$ shell length } & \multicolumn{3}{|c|}{$150 \mu \mathrm{m}$ shell length } & \multicolumn{3}{|c|}{$200 \mu \mathrm{m}$ shell length } & \multicolumn{3}{|c|}{$250 \mu \mathrm{m}$ shell length } \\
\hline & & $\mu \mathrm{m}$ & $\begin{array}{l}\mathrm{ng} \\
\mathrm{d}^{-1}\end{array}$ & $\begin{array}{c}\% \text { afdw } \\
\mathrm{d}^{-1}\end{array}$ & $\mu m$ & $\begin{array}{l}n g \\
d^{-1}\end{array}$ & $\begin{array}{c}\% \text { afdw } \\
\mathrm{d}^{-1}\end{array}$ & $\mu \mathrm{m}$ & $\begin{array}{l}\mathrm{ng} \\
\mathrm{d}^{-1}\end{array}$ & $\begin{array}{c}\% \text { afdw } \\
d^{-1}\end{array}$ & $\begin{array}{l}\mu \mathrm{m} \\
\mathrm{d}^{-1}\end{array}$ & $\begin{array}{l}\mathrm{ng} \\
\mathrm{d}^{-1}\end{array}$ & $\begin{array}{c}\% \text { afdw } \\
d^{-1}\end{array}$ \\
\hline \multirow{6}{*}{$6^{\circ} \mathrm{C}$} & 1 & 1.3 & 1.4 & 3.4 & 1.3 & 2.2 & 2.6 & 1.0 & 3.0 & 1.5 & - & - & - \\
\hline & 2 & 2.1 & 2.3 & 5.3 & 2.3 & 3.9 & 4.7 & 2.5 & 7.6 & 3.8 & - & - & - \\
\hline & 5 & 2.1 & 2.3 & 5.3 & 2.3 & 3.9 & 4.7 & 2.9 & 8.8 & 4.4 & 2.9 & 13.8 & 3.5 \\
\hline & 10 & 3.1 & 3.4 & 7.8 & 3.1 & 5.3 & 6.4 & 3.1 & 9.4 & 4.8 & 3.1 & 14.8 & 3.8 \\
\hline & 20 & 3.4 & 3.7 & 8.7 & 3.4 & 5.8 & 6.8 & 3.4 & 10.3 & 5.1 & 3.4 & 16.2 & 4.1 \\
\hline & 40 & 3.5 & 3.8 & 8.7 & 3.5 & 5.9 & 7.0 & 3.5 & 10.6 & 5.3 & 3.5 & 16.7 & 4.2 \\
\hline \multirow{6}{*}{$12^{\circ} \mathrm{C}$} & 1 & 1.2 & 1.3 & 3.1 & - & - & - & - & - & - & - & - & - \\
\hline & 2 & 2.9 & 3.1 & 7.3 & 2.9 & 4.9 & 5.8 & 2.9 & 8.8 & 4.4 & 2.9 & 13.8 & 3.5 \\
\hline & 5 & 4.7 & 5.1 & 12.0 & 4.7 & 8.0 & 9.5 & 4.7 & 14.3 & 7.2 & 4.7 & 22.4 & 5.8 \\
\hline & 10 & 8.1 & 8.8 & 20.4 & 8.1 & 13.8 & 16.2 & 8.1 & 24.6 & 12.2 & 8.1 & 38.6 & 9.8 \\
\hline & 20 & 7.8 & 8.4 & 19.5 & 7.8 & 13.2 & 15.8 & 7.8 & 23.7 & 11.8 & 7.8 & 37.2 & 9.4 \\
\hline & 40 & 6.8 & 7.4 & 17.3 & 6.8 & 11.5 & 13.8 & 6.8 & 20.6 & 10.3 & 6.8 & 32.4 & 8.2 \\
\hline \multirow{6}{*}{$18^{\circ} \mathrm{C}$} & 1 & 4.1 & 4.4 & 10.3 & 4.1 & 7.0 & 8.3 & - & - & - & - & - & - \\
\hline & 2 & 4.2 & 4.5 & 10.6 & 4.2 & 7.1 & 8.5 & 4.2 & 12.7 & 6.4 & 4.2 & 20.0 & 5.1 \\
\hline & 5 & 6.9 & 7.5 & 17.3 & 6.9 & 11.7 & 13.8 & 6.9 & 20.9 & 10.4 & 6.9 & 32.9 & 8.3 \\
\hline & 10 & 10.2 & 11.0 & 26.0 & 10.2 & 17.3 & 20.6 & 10.2 & 31.0 & 15.5 & 10.2 & 48.6 & 12.4 \\
\hline & 20 & 11.3 & 12.2 & 28.8 & 11.3 & 19.2 & 22.9 & 113 & 34.3 & 17.2 & 11.3 & 53.8 & 13.8 \\
\hline & 40 & 11.8 & 12.8 & 29.6 & 11.8 & 20.0 & 23.8 & 11.8 & 35.8 & 17.8 & 11.8 & 56.2 & 14.3 \\
\hline
\end{tabular}
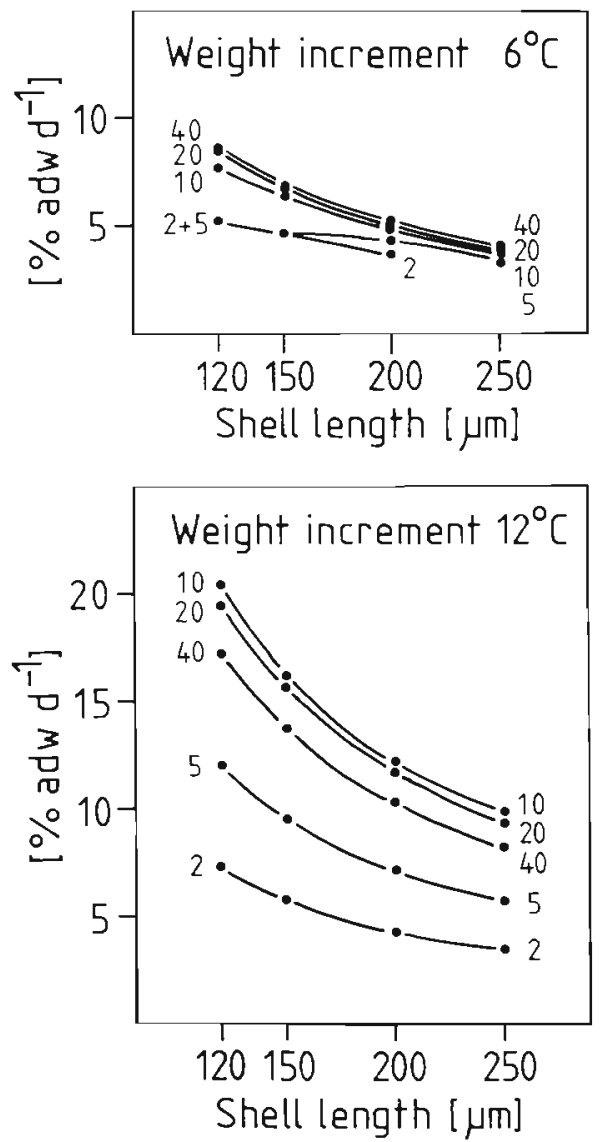

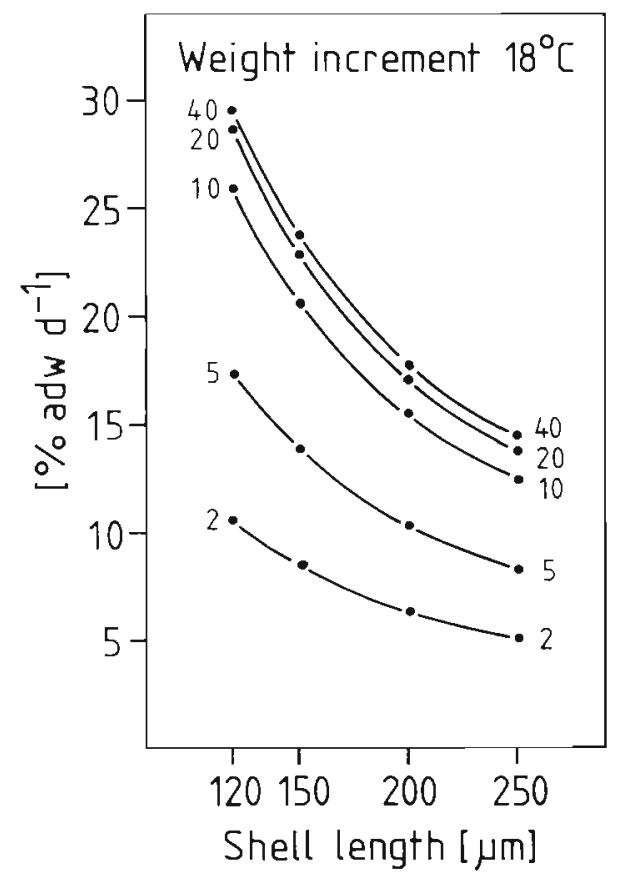

Fig. 6. Mytilus edulis, larvae. Relative increase in ash free dry weight per day at various food concentrations (Isochrysis cells $\mu l^{-1}$ ) and experimental temperatures; data from Table 3 


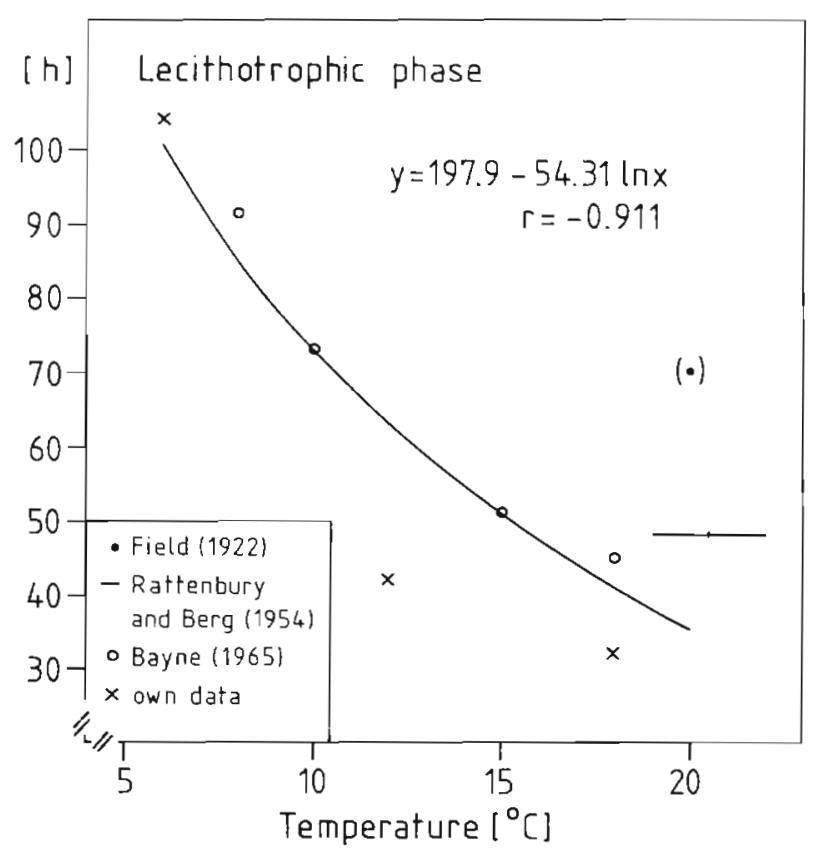

Fig. 7. Mytilus edulis, larvae. Duration of the lecithotrophic phase $(y)$ as a function of temperature $(x)$ (Field's data excluded $;$ r: correlation coefficient

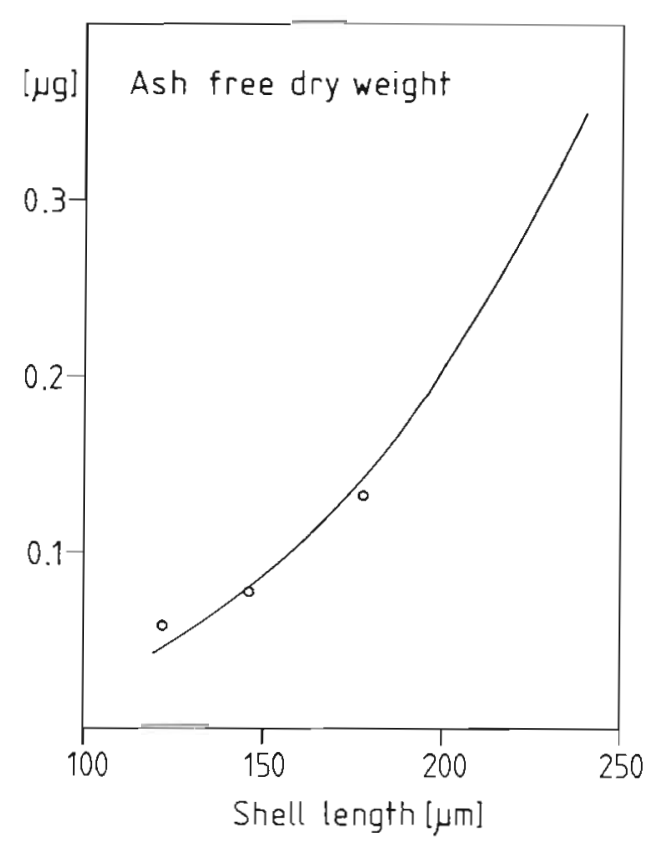

Fig. 8. Mytilus edulis, larvae. Three weight estimations of actively swimming larvae after a starvation period of $10 \mathrm{~d}$ and the graph from Fig. 3; see also text

(1980), Nascimento (1980), Jespersen and Olsen (1982) and Helm (cited by Bayne, 1983). In most cases data lay somewhat above the estimates reported here.
Holland and Spencer (1973) recorded a decrease of shell weight of Ostrea edulis larvae as a proportion of total weight with increasing larval size (from 83 to $73.5 \%$ over the whole size spectrum). This corresponds to my own findings and is also implied by the data of Jespersen and Olsen (1982). For this reason extrapolation of tissue weight from total dry weight simply by a constant factor is biased when examining the whole size spectrum.

Growth is influenced by a number of factors; some of them are discussed below.

\section{Food concentration}

Algal concentrations at which other authors reported optimal growth are summarized in Table 4. In dense larval cultures, the optimum can shift to higher food concentrations as demonsirated by Malouf and Breese (1977). This is, however, not the only factor explaining deviating results. Next to this, interactions are to be expected with larval size (Rhodes and Landers, 1973), rearing temperature as well as other factors.

At algal concentrations above the optimum, growth rates often decline. Two reasons may account for this: (1) dense algal concentrations hamper the feeding apparatus of the larva (Yonge, 1926); (2) bivalve larvae are known to react sensitively to dissolved substances (Loosanoff and Davis, 1963; Le Pennec et al., 1973; Sastry, 1979). Such dissolved substances may be algal metabolites (Davis, 1953; Loosanoff and Davis, 1963). Especially Isochrysis is known to produce substances toxic for bivalve larvae under certain conditions (Guillard, 1958). Apparently this is the reason why at $12^{\circ} \mathrm{C}$ a maximum has been attained so early. As Isochrysis had been cultivated at $10^{\circ} \mathrm{C}$, it may have ceased to produce metabolites in the 6 and $18^{\circ} \mathrm{C}$ cultures due to the temperature change, whereas at $12^{\circ} \mathrm{C}$ it might have continued.

\section{Larval density}

It is hardly feasible to conduct laboratory experiments with natural larval densities. Maximum values reported from natural assemblages range between 3 to

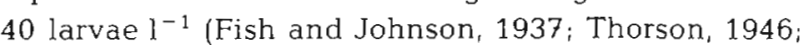
Rees, 1954; Schram, 1970; Hernroth and Ackefors, 1979). Larval growth rate is known to decline in laboratory cultures with increasing larval density (Davis, 1953; Loosanoff, 1954; Loosanoff and Davis, 1963). Possible reasons must be looked for in the number of collisions or the production of excretes. According to my own observations larval density has only minor effects on growth below 1 larva $\mathrm{ml}^{-1}$. 
Table 4. Literature data on optimum Isochrysis concentrations for bivalve larval rearing; Jespersen and Olsen's (1982) data for a mixture of Isochrysis and Monochrysis

\begin{tabular}{|lccl|}
\hline \multicolumn{1}{|c}{ Species } & $\begin{array}{c}\text { Larval } \\
\text { density } \\
\left(\mathrm{ml}^{-1}\right)\end{array}$ & $\begin{array}{c}\text { Optimum growth } \\
\text { condition } \\
\left.(\text { cells } \mu]^{-1}\right)\end{array}$ & Source \\
\hline Ostrea edulis & 1 & $50-100$ & Walne $(1956 ; 1959 ; 1963 ; 1966)$ \\
Ostrea edulis & 2 & 300 & Wilson (1979) \\
$\begin{array}{l}\text { Ostrea edulis and } \\
\text { Mercenaria mercenaria }\end{array}$ & $10-15$ & $50-400$ & Davis and Guillard (1958) \\
Crassostrea virginica & 15 & $25-325$ & Rhodes and Landers (1973) \\
Mytilus edulis & $3-10$ & 100 & Bayne (1965) \\
Mytilus edulis & $0.1-0.2$ & $40-50$ & Jespersen and Olsen (1982) \\
\hline
\end{tabular}

\section{Temperature}

For the development to the D-larva a $\mathrm{Q}_{10}$-value of 4.6 between 6 and $12^{\circ} \mathrm{C}$ and of 1.5 between 12 and $18^{\circ} \mathrm{C}$ can be calculated; for the maximum growth rate it is 4.0 and 1.9 , respectively. This may demonstrate that both processes are influenced by temperature in a similar way.

\section{Larval size}

With various bivalve species the following authors recorded different types of growth curves for larvae (shell length vs. time):

- exponential: e.g. Walne (1966), His and Robert (1982), Robert et al. (1982), Helm (quoted by Bayne, 1983):

- sigmoidal: e.g. Loosanoff et al. (1951), Walne (1956), Bayne (1965), Gerdes (1983a);

- linear: e.g. Ansell (1961), Carriker (1961), Walne (1965), Yoo (1969), Breese and Robinson (1981), Jespersen and Olsen (1982) and Lutz et al. (1982).

What the growth curve looks like and what kind of fit has to be applied, must be decided individually. The validity of a sigmoidal growth curve has been discussed by Bayne (1976). Gerdes (1983a) provides evidence that it is caused by a depressed feeding rate on the pediveliger stage when the larva starts reducing its velum.

In my own experiments at $6^{\circ} \mathrm{C}$, however, the growth curves leveled off far before reaching the pediveliger stage. Thus, sigmoidality must have different causes here. As will be demonstrated in a subsequent paper, the energy for swimming as a proportion of the measured respiration increases with larval size, especially at low temperatures. Possibly, in this case, the mussel has to spend so much energy to move that this affects growth.
According to the classification by Fry (1971; see also Brett, 1979), larval size is the limiting factor for larval growth. It is modified by the controlling effect of temperature and food concentration. This is manifested by the declining relative weight increase with larval size (Fig. 6).

Acknowledgements. This is a contribution to research project 'Experimentelle Marine Okosystemanalyse' sponsored by Bundesministerium für Forschung und Technologie, Bonn (Grant No. MFU-0328/1). It is based on parts of the author's doctoral thesis submitted to Kiel University. I am grateful to Professor Dr. W. Noodt for supervising the thesis; to Dr. K. Anger for helpful discussions of this paper; to Dr. E. Hagmeier for providing the algal cultures for the experiments; and to Dr. $M$. Rieper for correcting the manuscript. I am also indebted to Studienstiftung des Deutschen Volkes, Bonn-Bad Godesberg for financial support.

\section{LITERATURE CITED}

Ansell, A. D. (1961). Reproduction, growth and mortality of Venus striatula (Da Costa) in the Kames Bay, Millport. J. mar. biol. Ass. U. K. 41: 191-215

Bayne, B. L. (1965). Growth and the delay of metamorphosis of the larvae of Mytilus edulis L. Ophelia 2: 1-47

Bayne, B. L. (1971). Some morphological changes that occur at the metamorphosis of the larvae of Mytilus edulis. In: Crisp, D. J. (ed.) Fourth European Marine Biology Symposium, Bangor. Cambridge University Press, London, p. $259-280$

Bayne, B. L. (1976). The biology of mussel larvae. In: Bayne, B. L. (ed.) Marine mussels: their ecology and physiology. IBP 10, Cambridge University Press, London, p. 81-120

Bayne, B. L. (1983). The physiological ecology of marine molluscan larvae. In: Verdonk, N. H., van den, Biggelaar, J. A. M., Tompa, A. (ed.) The Mollusca, Vol. InI. Development. Academic Press, New York, p. 299-343

Bayne, B. L., Salkeld, P. N., Worrall, C. M. (1983). Reproductive effort and value in different populations of the marine mussel, Mytilus edulis L. Oecologia 59: 18-26

Booth, J. D. (1977). Common bivalve larvae from New Zealand Mytilacea. N. Z. J. mar. Freshwat. Res. 11: 407-440 
Breese, W. P., Robinson, A. (1981). Razor clams, Siliqua patula (Dixon): gonadal development, induced spawning and larval rearing. Aquaculture 22: 27-33

Brett, J. R. (1979). Environmental factors and growth. In: Hoar, W. S., Randall, D. J., Brett, J. R. (ed.) Fish physiology, Vol. VIII. Academic Press, New York, p. 599-675

Brousseau, D. J., Baglivo, J. A., Lang, G. E., Jr. (1982). Estimation of equilibrium settlement rates for benthic marine invertebrates: its application to Mya arenaria (Moliusca: Pelecypoda). Fish. Bull. Fish Wildl. Serv. U. S. 80: 642-644

Carriker, M. R. (1956). Biology and propagation of young hard clams, Mercenaria mercenaria. J. Elisha Mitchell scient. Soc. 72: $57-60$

Carriker, M. R. (1961). Interrelation of functional morphology, behaviour, and autecology in early stages of the bivalve Mercenaria mercenaria. J. Elisha Mitchell scient. Soc. 77 : $168-241$

Crisp, D. J. (1974). Energy relations of marine invertebrate larvae. Thalassia jugosl. 10: 103-120

Crisp, D. J. (1975). The role of the pelagic larva. In: Spencer Davies, P. (ed.) Perspectives in experimental biology, Vol. T. Pergamon Press, Oxford, p. 145-155

Davis, H. C. (1953). On food and feeding of larvae of the American oyster, $C$. virginica. Biol. Bull. mar biol. Lab., Woods Hole $104 ; 334-350$

Davis, H. C., Guillard, R. R. (1958). Relative value of ten genera of microorganisms as food for oyster and clam larvae. Fish. Bull. Fish Wildl. Serv. U. S. 58: 293-304

Field, I. A. (1922). Biology and economic value of the sea mussel Mytilus edulis. Bull. U. S. Bur. Fish. 38: 127-259

Finlay, B. J., Uhlig, G. (1981). Calorific and carbon values of marine and freshwater protozoa. Helgoländer Meeresunters. 34: 401-412

Fish, C. J., Johnson, M. W. (1937). The biology of the zooplankton in the Bay of Fundy and Gulf of Maine with special reference to production and distribution. J. biol. Bd Can. 3: 189-322

Fry, F. E. (1971). The effect of environmental factors on the physiology of fish. In: Hoar, W. S., Randall, D. J. (ed.) Fish physiology, Vol. VI. Academic Press, New York, p. 1-98

Gabbott, P. A., Holland, D. L. (1973). Growth and metabolism of Ostrea edulis larvae. Nature, Lond. 241: 475-476

Gerdes, D. (1980). Nahrungsaufnahme, Nahrungsausnutzung und Sauerstoffverbrauch der Auster Crassostrea gigas und ihrer Larve. Ph. D. thesis, University of Kiel

Gerdes, D. (1983a). The Pacific oyster Crassostrea gigas. Part I. Feeding and behaviour of larvae and adults. Aquaculture 31: 195-219

Gerdes, D. (1983b). The Pacific oyster Crassostrea gigas. Part II. Oxygen consumption of larvae and adults. Aquaculture 31: 221-231

Gledhill, C. (1980). The influence of established infauna on recruitment of the soft-shell clam, Mya arenaria L. M. S. thesis, University of Massachusetts

Guillard, R. R. (1958). Some factors in the use of nannoplankton cultures as food for larval and juvenile bivalves. Proc. natn Shellfish. Ass. 48: 134-141

Guillard, R. R. L., Ryther, J. H. (1962). Studies of marine planktonic diatoms. I. Cyclotella nana Hustedt and Detonula confervacea (Cleve) Gran. Can. J. Microbiol. 8: $229-239$

Gustafson, R. G. (1980). Dissolved free amino acids in the nutrition of larvae of the soft-shell clam Mya arenaria. M. S. thesis, University of Maine

Hernroth, L., Ackefors, H. (1979). The zooplankton of the Baltic proper A long-term investigation of the fauna, its biology and ecology. Fishery Board of Sweden, Report No 2: $1-60$
His, E., Robert, R. (1982). Le danger des traitements par le sulfate de cuivre en zone conchylicole: toxicité vis-a-vis des oeufs et des jeunes larves de Crassostrea gigas. Rev Trav. Inst. Pêches maritimes 45: 117-125

Holland, D. L., Spencer, B. E. (1973). Biochemical changes in fed and starved oyster, Ostrea edulis L., during larval development, metamorphosis and early spat growth. J. mar. biol Ass. U. K. 53: 287-298

Jespersen, H., Olsen, K. (1982). Bioenergetics in veliger larvae of Mytilus edulis L. Ophelia 21: 101-113

Jorgensen, C. B. (1952). Efficiency of growth in Mytilus edulis and two gastropod veligers. Nature, Lond. 170: 714

Jørgensen, C. B. (1983). Ecological physiology: background and perspectives. Comp. Biochem. Physiol. 75 A: 5-8

Kain, J. M., Fogg, G. E. (1958). Studies on the growth of marine phytoplankton. II. Isochrysis galbana Parke. J. mar. biol. Ass. U. K. 37: 781-788

Le Pennec, M., Prieur, D., Chardi, P. (1973). Développement larvaire de Mytilus edulis en présence d'antibiotiques. 2ème partie: action sur la croissance de 4 antibiotiques. Rev. Int. Océanogr. Méd. 30: 115-137

Le Pennec, M., Masson, M. (1976). Morphogénèse de la coquille de Mytilus galloprovincialis ( $m \mathrm{mk}$ ) élevé en laboratoire. Cah. Biol mar 17: 113-118

Le Pennec, M. (1980). The larval and post-larval hinge of some families of bivalve molluscs. J. mar. biol. Ass. U. K. 60: $601-617$

Loosanoff, V. L., Miller, W. S., Smith, P. B. (1951). Growth and settling of larvae of Venus mercenaria in relation to temperature. J. mar. Res. 10: 59-81

Loosanoff, V. L. (1954). New advances in the study of bivalve larvae. Am. Scient. 42: 607-624

Loosanoff, V. L., Davis, C. H. (1963). Rearing of bivalve mollusks. Adv mar. Biol. 1: 1-136

Lucas, J. S., Costlow, J. D. Jr. (1979). Effects of various temperature cycles on the larval development of the gastropod mollusc Crepidula fornicata. Mar. Biol. 51: 111-117

Lutz, R. A., Hidu, H. (1979). Hinge morphogenesis in the shells of larval and early post-larval mussels (Mytilus edulis L. and Modiolus modiolus L.). J. mar. biol. Ass. U. K. 59: 111-122

Lutz, R. A., Mann, R., Goodsell, J. G., Castagna, M. (1982). Larval and early post-larval development of Arctica islandica. J. mar biol. Ass. U. K. 62: 745-769

Malouf, R. E., Breese, W. P. (1977). Food consumption and growth of larvae of the Pacific oyster, Crassostrea gigas (Thunberg), in a constant flow rearing system. Proc. Matn. Shellfish. Ass. 67: 7-16

Matthews, A. (1913). Notes on the development of Mytilus edulis and Alcyonium digitatum. J. mar biol. Ass. U. K. 9 : $557-560$

Nascimento, I. A. (1980). Growth of the larvae of Crassostrea gigas Thunberg, fed with different algal species at high cell concentrations. J. Cons. int. Explor. Mer 39: 134-139

Rattenbury, J. C., Berg, W. E. (1954). Embryonic segregation during early development of Mytilus edulis. J. Morph. 95: 393-414

Rees, C. B. (1954). Continuous plankton records: the distribution of lamellibranch larvae in the North Sea, 1950-51. Bull. mar. Ecol. 4: 21-46

Rhodes, E., Landers, W. S. (1973). Growth of oyster larvae, Crassostrea virginica, of various sizes in different concentrations of the chrysophyte Isochrysis galbana. Proc. natn. Shellfish. Ass. 63: 53-59

Risggård, H. U., Randløv, A., Kristensen, P. S. (1980). Rates of water processing, oxygen consumption and efficiency of particle retention in veligers and young post-metamorphic Mytilus edulis. Ophelia 19: $37-47$ 
Riisgård, H. U., Randløv, A., Hamburger, K. (1981). Oxygen consumption and clearance in Mytilus edulis L. veliger larvae of different size. Ophelia 20: 179-185

Robert, R., His, E., Maurer, D. (1982). L'unité d'écophysiologie et de molysmologie larvaire des bivalves d'interet commercial du laboratoire I.S.T.P.M. d'Arcachon. Rev. Trav. Inst. Pêches maritimes. 45: 197-209

Sastry, A. N. (1979). Pelecypoda (excluding ostreidae). In: Giese, A. C., Pearse, J. S. (ed.) Reproduction of marine invertebrates, Vol V, Molluscs: Pelecypoda and lesser classes. Academic Press, New York, p. 113-292

Schram, J. A. (1970). Studies on the meroplankton in the inner Oslofjord. II. Seasonal differences and seasonal changes in the specific distribution of larvae. Nytt Mag. Zool. 18 $1-21$

Sprung, M. (1980). Das Frühjahrswachstum der Miesmuschel (Mytilus edulis L.) bei kontinuierlicher und diskontinuierlicher Nahrungszufuhr im Freiland-Biotop und unter Laborbedingungen. Diplomarbeit, University of Kiel

Sprung, M. (1983). Reproduction and fecundity of the mussel (Mytilus edulis) at Helgoland (North Sea). Helgoländer Meeresunters. 36: 243-255

Sprung, M. (1984). Experiments on nutritional stress on the larvae of the mussel Mytilus edulis L. In: Gray, J. S. Christiansen, M. E. (ed.) Eighteenth European Marine Biology Symposium, Oslo. Wiley, Chichester (in press)

Thompson, R. J. (1979). Fecundity and reproductive effort in the blue mussel (Mytilus edulis), the sea urchin (Strongylocentrotus droebachiensis), and the snow crab (Chionodectes opilio) from populations in Nova Scotia and Newfoundland. J. Fish. Res. Bd Can. 36: 955-964

Thorson, G. (1946). Reproduction and larval development of Danish marine bottom invertebrates. Meddr Kommn Danm. Fisk.-og Havunders., Ser. Plankton 4: 1-523
Walne, P. R. (1956). Experimental rearing of the larvae of Ostrea edulis L. in the laboratory. Fishery Invest, Lond. II 20: $1-23$

Walne, P. R. (1959). Some observations on the feeding behaviour of oyster (Ostrea edulis) larvae and their relation to rearing problems. Proc. 15th Intern. Congr Zool., London, p. 234-236

Walne, P. R. (1963). Observations on the food value of seven species of algae to the larvae of Ostrea edulis. J. mar. biol. Ass. U. K. 43: $767-780$

Walne, P. R. (1965). Observations on the influence of food supply and temperature on the feeding and growth of the larvae of Ostrea edulis. Fishery Invest., Lond. II 24: 1-45

Walne, P. R. (1966). Experiments in the large scale culture of the larva of Ostrea edulis L. Fishery Invest., Lond. II 25: $1-53$

Walne, P, R. (1979). Culture of bivalve molluscs. 50 years of experience at Conwy. Fishing News Books Ltd, Farnham

Wilson, J. H. (1979). Observations on the grazing rates and growth of Ostrea edulis L. larvae fed on algal cultures of different age. J. exp. Mar Biol. Ecol. 38: 187-199

Werner, B. (1940). Über die Entwicklung und Artunterscheidung von Muschellarven des Nordseeplanktons, unter gesonderter Berücksichtigung der Schalenentwicklung. Zool. Jb. (Anatomie) 66: 1-54

Yap, W G. (1977). Population biology of the Japanese littleneck clam, Tapes philippinarum, in Kaneohe Bay, Oahu, Hawaiian Islands. Pacif. Sci. 31: 223-244

Yonge, C. M. (1926). Structure and physiology of the organs of feeding and digestion in Ostrea edulis. J. mar biol. Ass. U. K. $14: 295-386$

Yoo, S. K. (1969). Food and growth of the larvae of certain important bivalves. Bull. Pusan Fish. Coll. 9: 65-87

This paper was presented by Professor H.-P. Bulnheim; it was accepted for printing on March 16, 1984 